\title{
The Roles of Administrators in Distance Education Programme: A Case at Higher Learning Institutions
}

\author{
Che Noraini Hashim, Bakare Kazeem Kayode, and Sharifah Sariah Syed Hassan
}

\begin{abstract}
This study examined the role of administrators in facilitating instructors and students of distance education programme (DEP) to the use of effective communication tools of the present digitized environment. Administrators/coordinators of DEP were purposively selected from three different universities in Malaysia. Their responses from interviews had been transcribed and coded. Students' feedback and monitoring activities on Learning Management System (LMS) were also collected and analyzed. Findings suggest that administrators did not consider certificate or experience in distance learning while recruiting instructors to teach in DEP. Instead, they perceived that university lecturers from the conventional programme should be able to fulfil course learning outcomes designed for the DEP. Evidence had shown that administrators bureaucratic decision in mandating LMS with grade attached, seemed to deter lecturers from using effective communication tools such as emails and facebook. When asked on plans to improve the administration of DEP, the administrators mentioned that training has really helped lecturers to improve their content delivery skills. It is concluded that the circumstantial or semester training through LMS which involved training among lecturers who are new in the e-learning environment is inadequate. The monitoring of DEP through the LMS is recommended to be focused on upgrading communication practices as well as attitudes among lecturers for effective online instructions which are critical to the eventual achievement of the DEP learners.
\end{abstract}

Index Terms-Administration, communication tools distance education, LMS, higher learning institutions.

\section{INTRODUCTION}

Distance education programmes (DEP) have fulfilled the educational aspiration of learner with the use of information technology that requires less human intervention. This development has led to a paradigm shift in management and administration of distance education [1]. Ironically, as distance education continued to gain momentum with the aid of distance education technology, educational administrators and coordinators are complacent to the demand of the current education milieu [2].

Copious academic and professional write-ups have been written about the management of distance education [2]. Surprisingly, most of these articles and reports had only being geared towards distance education policy relating to distance education delivery models. Issues related to leadership and administration involving recent technology-assisted instruction and flexible learning had

Manuscript received January 2, 2014; revised March 6, 2014. This research is designed and sponsored by the researchers.

The authors are with the Institute of Education International Islamic University Malaysia (e-mail: cnoraini@gmail.com, sariah1199@yahoo.com sharifahshahab@iiu.edu.my, kosimbakr@gmail.com). attracted little attention [3]. Thus, the need for distance education administrators to expand the resources and share their administrative functions which accommodate the role of educational technology [4] should become pertinent. It is the objective of this research therefore to investigate the role of education administrators in facilitating the use of effective communication tools among instructors and students of DEP.

Distance learning administrators are individuals who are saddled with the responsibilities of overseeing and coordinating all distance learning activities [5]. They planned and made decisions on course materials, recruitment and training of instructors and the use communication tools. In fact, distance learning administrators have extensive roles to accomplish. They have to manage not only the learning activities involved within the institutional environment, but also the wider online learning activities which that took place outside campus boudaries.

More so, technology-mediated activities and learning have permeated and modified the activities and role of administrators and leaders of distance learning programmes. The role of allocating resources, decision-making, monitoring online interaction and students' feedback are quite dynamic, due to rapid change in information technology. Consequently, educational entities must come-up with new management strategies that would fulfill the demand for education in the digitized global environment [6]-[9].

According to referece [9], one of the specific characteristics of administrators with regards to distance education, is to invest in a strategic plan that promote distance learning and traditional classroom learning equitably. Put differently, administrators in institution of higher learning must initiate and implement educational plan that leads to development of institution as a whole [9]. Subsequently, coordinators/administrators of different Units-Deans, Directors, Department Heads, will therefore be given opportunities to adopt and adapt the strategic directions parallel to the needs of their Units.

Administrators are also responsible for decision making on the presentation of course materials that encourage effective learnings, communication and interactions between students-content, student-lecturer and student-student [6]. Also, administrators/coordinators must ensure that all online course materials should be accessible to both students and instructors. Updating and monitoring of teaching material must also be on regular basis [5].

\section{RESEARCH DESIGN}

In selecting participants for the study, a purposive sampling technique was used. Three administrators were 
selected and a semi-structured interview protocol was applied to elicit responses from each participant. The purpose is to explore how administrators monitor and manage communication and interactions between instructors and learners in DEP, at each institution. Interviews weres conducted to better understand the processes involved in recruiting and training of instructors as well as to monitor how instructors managed communication between and among students. The criteria for selection include: (a) the individual must be administrator/coordinator of DEP at public institution of higher learning in Malaysia and (b) the individual must have administered the DEP for at least 6 months.

\section{A. Trustworthiness and Comfirmability}

Several issues can threaten the internal validity of the research. First, the level of honesty of the participants might limit the application of results from this study. The potential of response bias, which is the conscious or unconscious manipulation of verbal responses or behaviors, is another potential limitation [10]. The trustworthiness and comfirmability of the data obtained was done by sending the verbatim transcription of the interview data to the participants for reviewed. After cross-checking, the replies from participantswere used to confirm that the transcriptions were accurate. Furthermore, an inter-rater validity technique was also applied to validate the accurate of the selected themes. Inter-rater reliability is more frequently of concern in research studies or where the only interest is in consistency of raters' judgments about the relative levels of performance [12]. The kappa inter-rater reliability test give $82.4 \%$ reliability from two raters confirming the adequacy and consistency of the emerging themes.

\section{DATA ANALYSIS PROCEDURE}

The qualitative data analysis process started with a complete transcription of all verbatim responses from participants. The first process was to document all statements that were relevant to the experience and group them in high-level categories. In the second step, each statement was clustered according to the research question by coding, in order to determine the main idea and the frequency of occurrence of each main idea. Next, each statement was tested to determine whether or not it could be abstracted as a theme or it contained an element necessary to the understanding the participants' experience. Step four involved modified data analysis method in which data are coded into main idea from which all statements would be clustered into labeled thematic groups [10], [11]. A general coding scheme, based on description of [11] was created to provide a conceptual and coherent order to the emerging codes and subsequent themes. Themes were then validated by reviewing the complete participant's transcription to determine whether or not the themes were explicitly expressed or were easily compatible.

\section{RESULT}

\section{A. Demographics Information of Participant}

The participants comprises one male — a PhD holder, 42 years old lecturer and Program Pensiswazahan Guru (PPG), a distance education coordinator. As for the other two females, one of them is a $\mathrm{PhD}$ degree holder, a 48 years old lecturer and also a coordinator of PPG distance education programme. The third participant is a Masters Degree holder, a 38years old lecturer and also a DEP coordinator.

\section{A. Role of Distance Learning Programme Administrator in Facilitating Effective Communication}

TABLE I: ROLES OF ADMINISTRATOR IN DEP

\begin{tabular}{|c|c|c|c|c|}
\hline $\begin{array}{l}\text { Interview } \\
\text { questions }\end{array}$ & $\begin{array}{l}\text { Phenomenon } \\
\text { as a Statement } \\
\text { Presented by } \\
\text { administrator } \\
\text { s }\end{array}$ & $\begin{array}{l}\text { The } \\
\text { Essential } \\
\text { Meaning } \\
\text { Revealed } \\
\text { by } \\
\text { Phenomen } \\
\text { ological } \\
\text { Reduction }\end{array}$ & $\begin{array}{l}\text { Meanin } \\
\text { g Code }\end{array}$ & Theme \\
\hline $\begin{array}{l}\text { Describe } \\
\text { the } \\
\text { procedure } \\
\text { s involved } \\
\text { in } \\
\text { recruiting } \\
\text { instructors } \\
\text { assigned } \\
\text { to teach in } \\
\text { the DEP? }\end{array}$ & $\begin{array}{l}\text { R1 } \\
\text { "Instructors' } \\
\text { teaching } \\
\text { qualification } \\
\text { was deemed to } \\
\text { be an important } \\
\text { criterion that is } \\
\text { used to recruit } \\
\text { instructors to } \\
\text { teach in } \\
\text { distance } \\
\text { learning } \\
\text { programme". } \\
\text { R2 "I mean, } \\
\text { through our } \\
\text { lecturers who } \\
\text { know other } \\
\text { lecturers with } \\
\text { suitable } \\
\text { qualification." }\end{array}$ & $\begin{array}{l}\text { Traditional } \\
\text { teaching } \\
\text { qualificatio } \\
\mathrm{n} \text { and } \\
\text { specialized } \\
\text { of } \\
\text { instructors } \\
\text { are the } \\
\text { essential } \\
\text { criteria } \\
\text { these } \\
\text { administrat } \\
\text { ors look for } \\
\text { in } \\
\text { recruiting } \\
\text { lecturers } \\
\text { for } \\
\text { distance } \\
\text { learning } \\
\text { programme }\end{array}$ & $\begin{array}{l}\text { Repeatin } \\
\mathrm{g} \\
\text { procedur } \\
\text { es for } \\
\text { Recruitin } \\
\mathrm{g} \\
\text { classroo } \\
\mathrm{m} \\
\text { lecturers }\end{array}$ & $\begin{array}{l}\text { Suitable } \\
\text { teaching } \\
\text { qualificati } \\
\text { on }\end{array}$ \\
\hline \multirow{2}{*}{$\begin{array}{l}\text { How do } \\
\text { you ensure } \\
\text { that } \\
\text { instructors } \\
\text { had } \\
\text { organized } \\
\text { and } \\
\text { establishe } \\
\text { d } \\
\text { interaction } \\
\text { between } \\
\text { course } \\
\text { content } \\
\text { and the } \\
\text { students? }\end{array}$} & $\begin{array}{l}\mathrm{R} 1 \text { ".......it is } \\
\text { compulsory for } \\
\text { each lecturer to } \\
\text { have a } \\
\text { minimum five } \\
\text { eeh forums per } \\
\text { a semester }\end{array}$ & \multirow{2}{*}{$\begin{array}{l}\text { Rationalizi } \\
\text { ng the need } \\
\text { to include } \\
\text { coordinatio } \\
n \text { and } \\
\text { monitoring } \\
\text { of } \\
\text { technologi } \\
\text { cal-mediu } \\
\text { m of } \\
\text { instruction } \\
\text { in distance } \\
\text { education } \\
\text { Rigid } \\
\text { decision on } \\
\text { the choice } \\
\text { and } \\
\text { communic } \\
\text { ation } \\
\text { medium } \\
\text { Undermini } \\
\text { ng regular } \\
\text { training for } \\
\text { distance } \\
\text { education } \\
\text { lecturer }\end{array}$} & \multirow[t]{2}{*}{$\begin{array}{l}\text { Roles } \\
\text { expected } \\
\text { of } \\
\text { distance } \\
\text { learning } \\
\text { administ } \\
\text { rators }\end{array}$} & \multirow{2}{*}{$\begin{array}{l}\text { Monitorin } \\
\mathrm{g} \text { forum } \\
\text { activities } \\
\text { feedbacks } \\
\text { Learning } \\
\text { Managem } \\
\text { ent } \\
\text { System } \\
\text { (LMS) } \\
\text { semester } \\
\text { training }\end{array}$} \\
\hline & $\begin{array}{l}\text { R2 } \\
\text { ".....lecturers } \\
\text { provide lecture } \\
\text { note, they also } \\
\text { provide } \\
\text { supporting } \\
\text { documents" } \\
\text { R2 it is } \\
\text { compulsory for } \\
\text { R3 "we give } \\
\text { training for } \\
\text { lecturers at the } \\
\text { beginning of } \\
\text { every } \\
\text { semesters on } \\
\text { how to manage } \\
\text { LMS.lecturers } \\
\text { to use this } \\
\text { LMS." }\end{array}$ & & & \\
\hline
\end{tabular}

The above central phenomenon was research question of the present study which dealt with issues relating to the roles of administrators in DEP. Effective communication has been identified to be a major factor that contributes to the engagement in distance learning [5]. Therefore, the present study focused on how distance learning administrators of the 
three selected universities manage, monitors and improve communication and interactions between distance learning instructors and learners to promote self-regulated learning. A review of the responses to the interview questions and association of the data with coding and thematic labels completed the theme development validation process the five emergent themes are (i) suitable teaching qualification, (ii) Monitoring of forum activities (iii) feedbacks (iv) university learning platform (LMS) (v) semester training. Table I showed how these themes are derived from the interview schedules.

\section{FINDINGS AND DisCUSSION}

The findings showed that the administrators/coordinators did not consider experience of instructors 'in teaching online, certificate in online course and capability of the instructors to handle communication tools' as the recruitment criteria for selecting tutors vis-à-vis lecturers and assigned them into the DEP. The three participants seemed to share similar criteria for recruitment of instructors. This finding seemed to contradict with finding reported by [14] and [6] that distance learning instructors' mut be able to manage the software as well as the communication to deliver distance learning.

Result also showed that monitoring feedbacks and forum activities while using technology such as Learning Management System (LMS) is in agreement with finding forwarded by [15]. This present study also revealed that administrators/coordinators of DEP need to focus on upgrading communication practices as well as attitude among lecturers for effective online instructions and ensure students' engagement.

This finding is supported by [7] who asserted that instructors could implement effective teaching by ensuring constant and frequent feedbacks from students and by monitoring students' limitations. It can be deduced from the interview response that the use of communication tools such as email, facebook and blog could facilitate effective communication and learning in the absence of the officially mandated medium LMS [13].

The information obtained from the two participants had indicated that much had not been attempted by administrators to improve the communication skills among DEP's instructors in handling and using the mandated communication tools. Since most of these instructors had no prior experience in teaching and managing communication in learning at a distance, semester or occasional training might not really provide them with all the skills required to teach online. While refernce [5] suggested that distance learning administrators must provide adequate training for instructors who were assigned to teach in DEP.

\section{CONCLUSION}

The emergent themes from the data suggested that the criteria used by administrators of in recruiting DEP's instructors did not consider certificate or experience in distance learning while recruiting instructors to teach in DEP. Instead, they perceived that university lecturers from the conventional programme should be able to fulfil course learning outcomes designed for the DEP. Evidence had shown that administrators bureaucratic decision in mandating LMS with grade attached, seemed to deter lecturers from using effective communication tools such as emails and facebook to communicate and interact with students. The DEP administrators also mentioned that training has really helped lecturers to improve their content delivery skills. It is concluded that the circumstantial or semester training through LMS which involved training on skills for online instructions among lecturers who are new in the e-learning environment is inadequate.

\section{ACKNOWLEDGMENT}

Administrators and leaders of distance learning programmes must aim at securing commitment from all levels, especially top administration, to overcome communication and instructional barriers as well as to combat attitudinal problems among instructors and learners. Leadership of DEP must offer ongoing trainings, seminars and workshops that deal with teaching at a distance, on top of the effective application of instructional technology. These trainings will have significant implications for distance education leadership, as it signifies the implementation of effective communication and virtual instructional practices, which are critical to the eventual achievement of the DEP learners.

\section{REFERENCES}

[1] J. Lee, "Instructional support for distance education and faculty motivation, commitment, satisfaction," British Journal of Educational Technology, vol. 32, no. 2, pp. 153-160, 2001.

[1] M. Beaudoin, "The instructor's changing role in distance education," The American Journal of Distance Education, vol. 4, no. 2, pp. 21-29, 1999

[2] J. C. Taylor, "Distance education technologies: The fourth generation," Australian Journal of Educational Technology, vol. 11, no. 2, pp. 1-7, 1996.

[3] J. Styron, S. Wang, and R. Styron, "Consideration of distance education integration: A qualitative study," Journal of Educational Technology Development and Exchange, vol. 2, no. 1, pp. 79-98, 2009

[4] B. H. Khan, "Managing e-learning strategies: design, delivery, implementation and evaluation," Information Science Publishing, United State, 2005.

[5] M. G. Moore and G. Kearsley, Distance Education: A Systems View, New York: Wadsworth, 2005.

[6] C. Angelaki, "Communication and social presence: the impact on adult learners' emotions in distance learning Turkish online," Journal of Distance Education, vol. 6, no. 2, 2013.

[7] M. B. Qureshi, N. K. Shahzadi, J. Iqbal, and M. C. Ajmal, "Leadership and distance learning: a demand for quality education," in Proc. the 2nd International Conference on Business Management Pakistan, 2012

[8] W. D. Care and J. M. Scanlan. (2013). Planning and managing the development of courses for distance delivery: Results from a qualitative study. Online Journal of Distance Learning Administration. [Online]. $\quad 4 \quad$ (2). $2001 . \quad$ Available: http://www.westga.edu/ distance/ojdla/summer42/care42.html

[9] J. W. Creswell, Educational Research: Planning, Conducting, and Evaluating Quantitative and Qualitative Research, Upper Saddle River, NJ: Pearson, 2005

[10] M. B. Miles and A. M. Huberman, Qualitative Data Analysis: An Expanded Sourcebook, Thousand Oaks, CA: Sage, 1994.

[11] M. Graham, A. Milanowski, and J. Miller, "Measuring and promoting inter-rater agreement of teacher and principal performance ratings," Center for Educational Comparison Reform, 2012.

[12] K. M. Rahman and R. A. Sadat, "Enhancing distant learning through email communication: A case of Bou Turkish online," Journal of Distance Education-Tojde, vol. 9, no. 2, 2008.

[13] D. Valentine, "Distance learning: promises, problems, and possibilities," Online Journal of Distance Learning Administration, vol. 5, no. 3, pp. 1-11. 2002 
[14] D. Ravi and L. Pamela, Paving the Way towards an Efficient Learning Management System ACMSE'04, April 2-3, 2004, Huntsville, Alabama, USA, Copyright 2004 ACM 1-58113-870-9/04/04, 2004.

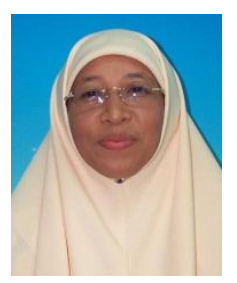

Che Noraini is an associate professor at Institute of Education (Insted), International Islamic University Malaysia. She has 23 years of teaching experience ( 20 years as a lecturer and 3 years as school teacher). In 2000, she was seconded to University of Sultan Zainal Abidin (UniZa) and became Dean, School of Education 2002-2004. She specializes in economics of education and teaching pedagogy and curriculum and instructions. She obtained a PhD in economics of education (Birmingham University) in 1995, masters in education and international managemen (Birmingham) in 1992, bachelor in economics (IIUM) in 1986, diploma in education (IIUM) in 1987 and a diploma in business studies (UiTM) in 1983. Her works include the Muslim world and the West; the potential educational institutions in building bridges in the context of Malaysia in 2007, Islamic religious curriculum in Muslim countries in 2008, human capital and organizational performance in 2009, learners' expectation on classroom communication in 2010. Her latest completed and published research in refereed international journals are Investigating Educational Leadership Practices Model among teachers in Malaysian Secondary Schools (funded by FRGS, IIUM research grant) and Factor Structure of Islamic Techniques for managing Stress Questionniare (December 2010). 